carnavales, era tradicional en muchas ciudades españolas desde la Edad Media como un juego o desahogo infantil tolerado. Según el Espasa, la primera acepción de obispillo es: «Muchacho que en algunas catedrales viste de obispo la víspera y día de San Nicolás de Bari» ${ }^{7}$.

\title{
ENRIQUE GARCÍA-HERRAIZ
}

Miembro de A.I.C.A.

\section{UN LIENZO DE LOS SENTIDOS DE JEAN COSSIERS}

A Jean Cossiers se le atribuye este lienzo de colección privada en Madrid (Fig. 7), pintor del ámbito de Rubens, del que conocemos tres lienzos en el Museo del Prado, (n. ${ }^{\text {ss }}$ 1463, 1464, 1465), pero copias de bocetos de Rubens para la decoración de la Torre de la Parada ${ }^{1}$, para lo que el pintor fue seleccionado por el Cardenal Infante entre los más destacados de la escuela de Amberes, bajo la dirección de Rubens.

Un cuarto lienzo está en el Palacio Real, identificado por quien esto escribe ${ }^{2}$. Todas son obras para el mismo conjunto, y afines a la estética del barroco del maestro; pero la pintura que aquí se da a conocer es diferente, pues corresponde a la etapa tenebrista del pintor y de invención propia. El acierto de esta composición vivaz y receptiva, de belleza cromática y gestos expresivos, fue motivo de varias réplicas, cuyo conocimiento ha contribuido a esclarecer la paternidad de la que se estudia aquí.

sa

El joven lo repite en el n. ${ }^{\circ} 38$ del Museo de Amberes, la Sagrada Familia del Louvre y Alegorías de las galerías Marcus Bens y R. Grem de Londres; y la mujer es la misma en la versión de la colección de Sir Félix Cassel (Fig. 8), duque de Albercort (L.128 X 191) ${ }^{3}$. Debió gustar esta composición, pues Cossiers hizo una tercera réplica, que poseyó $\mathrm{K}$. Loevench en Nueva York ${ }^{4}$.

Las figuras de medio cuerpo siguen esquemas de Caravaggio, pero esto es frecuente en el siglo XVI, lo hace Massys con un tema igual: los Sentidos del Museo de Estocolmo. Aquí reviven las mismas imágenes y con igual intencionalidad. Más próxima es la versión de Finsonius en el Erzog Antón Ulbrich Museum, y los grabados de A. Collaert, según A. Van Noort. J. Cossiers pudo conocerlos.

Estamos frente a una alegoría de los Sentidos cuyo contenido fue desconocido. Los personajes - de diferentes edades- no llevan signos alegóricos, tan típicos en los grabados italianos y flamencos de los siglos XVI y XVII, igual que en Caravaggio y satélites los omite, asumiendo la realidad desnuda, lo que dificulta la lectura de su mensaje.

7 En la catedral de Sevilla la víspera del día de los Inocentes, en la Navidad, se elegía como obispillo al menor de los niños cantores llamados seises, el cual, seguido de una grotesca corte, al oirse cierto versículo del canto Magnificat, desalojaba en medio del jolgorio popular a los viejos canónigos de sus sillas del coro (Diccionario Enciclopédico Espasa).

1 Díaz Padrón, M.: El Siglo de Rubens en el Museo del Prado, Madrid 1995, I, p. 374.

2 Díaz Padrón, M.: Homenaje a P. P. Pablo Rubens (1977-1978), Palacio de Velázquez, p. 39, n. 16.

3 Vendido a Christie's (Londres, 21, I, 1954, n. ${ }^{\circ} 150$ ).

4 Dayton, Art Institut ( . $^{\circ}$ 55.74), legado Robert Badenshon, vendido en la galería Christie's de Nueva York (19-1-1984, n. $\left.{ }^{\circ} 58\right)$. 

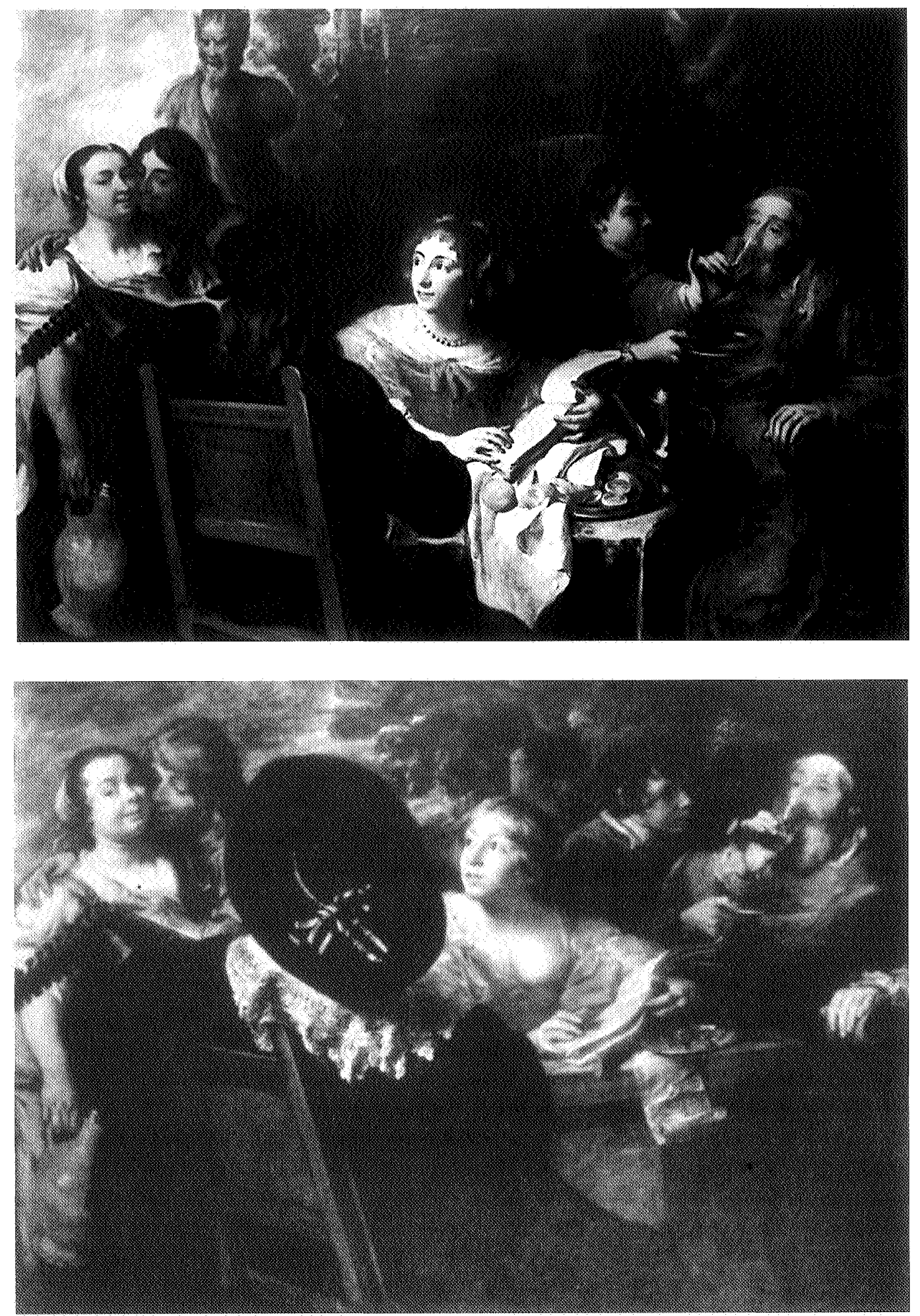

Figura 7. Jan Cossiers: Los Sentidos. Madrid. Colección particular. Conjunto y detalle.

Figura 8. Jan Cossiers: Los Sentidos. Colección aunque en Albercort (Londres). 
El Tacto del grabado de A. Collaert (1560-1618) de la serie de los Sentidos de Adam van Noort (1562-1641), tiene igual lectura que la tabla de Rubens y Brueghel en el Tacto del Museo del Prado, y lienzo de Cossiers. Están en los límites de la lujuria. Otras fuentes están en Saenredam, según dibujos de Goltzius ${ }^{5}$, Joan Baeck, Cormelis van Kittansteyn y A. Aylery.

En J. Cossiers, la joven criada soporta el acoso del cliente condescendientemente, sin indicios de continuidad más allá de lo que está a la vista.

El sentir de las caricias de su compañero prefigura el Tacto; la segunda mujer de superior condición social y leyendo una partitura, simboliza la Vista, el Oído le acompaña: pero la joven domina, expresiva y formalmente la composición. Esto no es casual, pues la Vista preside las Series. Jean Cossiers asume la idea jerárquica de la tradición clásica.

Para Aristóteles la Vista es el más noble de los cinco sentidos ${ }^{6}$. Ripa sigue la misma idea en su Iconología, y Mathan y Goltzius en sus grabados. El laúd es símbolo del Oído 7. El modelo del laúd con 21 cuerdas fue identificado por Mirimonde al tratar la réplica de la colección de Sir Félix Cassel ${ }^{8}$. El Gusto está asociado con el anciano con el vaso de vino en alto.

La tradición mitológica está en la piel de leopardo que lleva a sus espaldas éste. Es atributo de Baco ${ }^{9}$; y la copa que lleva a sus labios, también es signo inequívoco del Gusto, que divulgan los grabados de C. Cort, M.P. Saenredam, Ch. Van de Passe, A. Collaert y G.M. Mitteli ${ }^{10}$.

La personificación del Olfato está en el joven con un recipiente que aproxima al anciano. Quizá la proximidad del vino es también alusión al Olfato, pues Ripa dice: «il vaso significa el olor artificial» ${ }^{11}$.

También el fauno y la fuente con Cupido en piedra lo divulga A. Collaert eñel fondo de los jardines. Los ojos del fauno asumen connotaciones humanas al dirigir su mirada insidiosa a la pareja de enamorados ${ }^{12}$. De otra parte, Cupido representa la virtud y la castidad frente al vicio ${ }^{13}$. El mito y la realidad cotidiana conviven en esta pintura, que busca el goce de los sentidos, por vía del amor sin olvidar la fertilidad. Cossiers se distancia de los extremos de lujuria que gusta a sus contemporáneos italianos y holandeses.

M. DÍAZ PADRÓN Museo del Prado

\footnotetext{
5 Bartsch, The Ilustrated Bartsch, Abans Book, Nueva York, 1971-1972, IV, pp. 95-99.

${ }^{6}$ De Sensi Cremona, 1997, I, 437 (cit. I que Sensi nell'arte, p. 24.

7 Bastsch, ob cit., 1992, IV, p. 274.

8 G. de Tervarent, Atributtis et symboles dans L'art profane, 1450-1604, Ginebra, 1958, p. 295.

9 Les Sujets de musique chez les Caravaggistes flamands, Jarboeck 1965, Koninklijk Museum Voor Schone Kusten, Antwerpenr, 1965, p. 159.

${ }_{10}$ Philostrato, Imagines, I. 15.

1 Cinque sensi nell'arte, pp. 111, 119, 223 y 226; Leo Palniscig, Die Estensische Juntsammlung, Viena, 1919, Fig. 431.

i2 G. de Tervarent, ob. cit., 1958, p. 394.

13 Philostrato, ob. cit., I. p. 22.

14 Tervarrent, ob. cit., 1958, p. 26.
} 